\title{
The Supervised Teaching Practice and the Preservice Teachers' Intended and Performed Actions in a Chemistry Class
}

\author{
Natany Dayani de Souza Assai iDa \\ Sergio de Mello Arruda iDa \\ Fabiele Cristiane Dias Broietti \\ ${ }^{\text {a }}$ Universidade Estadual de Londrina, Programa de Pós-Graduação em Ensino de Ciências e Educação \\ Matemática, Londrina, PR, Brazil
}

Received for publication on 12 Oct. 2020. Accepted after review on 14 Dec. 2020

Designated editor: Claudia Lisete Oliveira Groenwald

\begin{abstract}
Background: Giving up prescriptive views on the teacher's action in the classroom is necessary for a better understanding of the teaching work. We are also faced with the absence of works that address teaching action under an investigative bias in initial teacher education. Objectives: identify and categorise the actions intended and performed by preservice teachers in a chemistry class, looking for implications for teacher education. Design: the study fits into a qualitative-interpretative research perspective. Setting and Participants: The data analysed comes from the monitoring of chemistry teaching degree students in the Supervised Teaching Practice discipline and their teaching in a $9^{\text {th }}$-grade class in a public school. Data collection and analysis: data collection took place through different instruments: lesson plans and audio and video recordings of the classes, that enabled interpretations based on the assumptions of the textual discursive analysis. Results: for the actions intended, a small set of five actions was identified (question, write, explain, organise, identify). The actions carried out, on the other hand, include a larger set of 13 actions and, mainly, microactions, made possible by the actions intended. There is a convergence between the actions initially planned and development in the departments, and the emergence of specific actions in the context of the Supervised Practice. Conclusions: Such results indicate the importance of categorising the actions of the undergraduate students in a chemistry class, resulting in a set of actions not yet identified in other studies, and discussing the importance of the Teaching Practice in the constitution of elements of the teaching work.
\end{abstract}

Keywords: Teacher action; Chemistry teaching; Supervised Teaching Practice; Initial teacher education.

Autor correspondente: Natany Dayani de Souza Assai. Email: natanyassai@gmail.com 


\section{O estágio supervisionado e as ações pretendidas e executadas por licenciandos em uma aula de Química}

\section{RESUMO}

Contexto: Abdicar de visões prescritivas sobre a ação do professor em sala de aula torna-se necessário para uma melhor compreensão do trabalho docente. Também nos deparamos com a ausência de trabalhos que abordam a ação docente sob um viés investigativo na formação inicial de professores. Objetivos: identificar e categorizar as ações pretendidas e executadas por licenciandos em uma aula de química, buscando implicações para a formação docente. Design: o estudo enquadra-se em perspectiva qualitativa-interpretativa de pesquisa. Ambiente e participantes: acompanhamento de uma dupla de estagiários do curso de Licenciatura em Química na disciplina de Estágio Supervisionado e suas respectivas regências em uma turma do $9^{\circ}$ ano da rede pública de Ensino. Coleta e análise de dados: A coleta de dados ocorreu mediante instrumentos distintos: planos de aula e gravações em áudio e vídeo das aulas, que possibilitaram interpretações e análise pautadas nos pressupostos da Análise Textual Discursiva. Resultados: para as ações pretendidas, identificou-se um pequeno conjunto com cinco ações (questionar, escrever, explicar, organizar, identificar). Já as ações executadas contemplam um conjunto maior de 13 ações e, principalmente, microações, possibilitadas pelas ações pretendidas. Há uma convergência entre as ações planejadas inicialmente e desenvolvimento nas regências, assim como emergência de ações específicas ao contexto do Estágio Supervisionado. Conclusões: Tais resultados sinalizam a importância de categorizar ações dos licenciandos em uma aula de Química, resultando em conjunto de ações ainda não identificados em outras pesquisas, e discutir a importância do Estágio na constituição de elementos do trabalho docente.

Palavras-chave: ação docente; ensino de química; estágio supervisionado; formação de professores.

\section{INTRODUCTION}

One of the main aspirations of teachers who work with initial and continuing education at different levels of education lies in qualifying professionals to construct a quality school, committed with its students' learning. For this, Azzi (1998, p. 35) attributes it as essential for schools to have teachers who "master the process of their work: the teaching work". But after all, what, in fact, configures the teacher's work in the classroom? 
To analyse a teacher's work, we must leave aside the moralising and normative understandings of teaching based on a prescriptive view that is interested, first of all, in what teachers should or should not do, without taking into account what they actually do and the reasons that lead them to take particular conducts in their daily actions in the classroom (Tardif \& Lessard, 2014).

Goulart and Vermelho (2019) affirm the need to think of teaching action as an interdependent process between teaching and learning, because the primary purpose of the teacher's action in their daily activities is oriented to their students' learning. We can also expand this idea by considering the conditions in which this action occurs, since such an interdependent process of teaching and learning is not linear and objective, given the complexity of the dynamic work environment of the teacher, as Tardif and Lessard (2014) point out.

The notion of "workload" is complex because it refers to several intersecting phenomena - several are non-quantifiable whose reciprocal influence is difficult or impossible to separate completely. Here are the main factors:

- $\quad$ Material and environmental factors, such as the nature of workplaces and material resources available;

- Social factors, such as the school location, the socioeconomic situation of the students and their families, violence, etc.

- $\quad$ Factors linked to the "object of work," such as class size, students' diversity, students with special needs, difficulties in adaptation and learning, etc.

- Phenomena resulting from work organisation: working time, content, employment relationship, diversity of tasks beyond teaching, etc.;

- Formal or bureaucratic requirements to be met: mandatory meetings, etc.

- There are still the ways teachers deal with those phenomena and strategies that they elaborate to assume or 
avoid (Tardif \& Lessard, 2014, p.113).

The typical workday, collective work in opposition to teacher individualism, school system organisation and the interactive fundamentals of teaching constitute some elements to be highlighted to interpret the teacher's activity. It follows that the object of the teacher's work is the human relations, occurring interactively, constituting a complex activity, dependent on the context of action, i.e., it is difficult to be based on prescriptions. Therefore, it becomes promising to think of the teaching activity in a reflective dimension, understanding the bases that guide the teacher's action.

In this sense, several authors (Murta, 2008; Barros, 2013; Quadros \& Giordan, 2019) argue that investigating the teacher's activity implies understanding the personal meanings and senses when it occurs. Basso (1998) reiterates that the school material conditions can trigger different activities that depend on the teacher, given the individuals' subjectivity. Murta (2008) reaffirms the need to analyse the teacher's facial and verbal expressions in the classroom to approach the possible reasons that mobilise the subject to do a specific action or activity. Quadros and Giordan (2019, p.96) present a semiotic bias by reiterating the importance of analysing the multirepresentations "mobilised in the action of teachers and students, which implies considering them part of a broader representational framework." Against this idea, Barros (2013) understands that didactic gestures are verbal and non-verbal directed to a teaching object, which must be evidenced so as to "unveil" the teacher's work - understand the teacher's "real" work to the detriment of a prescriptive and idealised work.

Thus, the interactivity of the teacher's work is not limited to the communicative dimension, nor only to physical actions and observable behaviours; it is a mixture between the verbal and the non-verbal, in which the meaning of the action happens while occurring. We understand, therefore, that it is fundamental to expand the senses and meanings attributed to teaching practice to assist in the process as a whole: whether in teacher initial or continuing education, or in student learning.

Therefore, we assumed that the teaching action is not restricted to the teacher's discourse in interviews or questionnaires, but in what we observed the teacher do in the classroom, to describe and categorise, using as support verbs that indicate action. 
Given this, some studies followed this investigative trend on teaching action (Andrade, 2016; Andrade \& Arruda, 2017; Andrade, Arruda \& Passos, 2018; Dias, 2018), presenting results about the categories of teaching action in mathematics classes in basic education. Our proposal for this research is to investigate future chemistry teachers' actions in planning and teaching a chemistry lesson in their school subject Supervised Teaching Practice. This proposal and the investigations above are part of a research program that studies the teaching actions, student actions, and connections in science and mathematics classes (Arruda \& Passos, 2017).

About initial teacher education, Pimenta and Lima (2012) define the mandatory curricular component Supervised Teaching Practice as a space of professional construction where undergraduates establish their initial relationships with the school environment. Raymundo (2011) conducts a historical and conceptual review of the curricular components of teaching practice and supervised teaching practice.

It enables reflection on teaching practice, allowing students moments of knowledge construction through reflection, analysis, and problematisation of this practice, and appraisal of tacit knowledge present in the solutions professionals find in the act. [...], teachers are helped to understand their thinking and reflect critically on their practice, improve their way of acting, and organise new instruments of action. (Raymundo, 2011, p.158)

Besides the numerous contributions of the Supervised Practice, we should highlight the possibility of re-signifying the necessary knowledges for the teachers' qualification. Thus, the preservice teachers exercise and apprehend fundamental competences to exercise teaching, by alternating moments of students' formation both in university and the practice field, opposing academic discussions the current reality and real teaching situations.

Considering the Supervised Teaching Practice as a formative space that provides the undergraduates with that experience and dialogue with the teaching work, we chose this investigation field motivated by the following questions: What actions do preservice teachers plan for a chemistry class? What actions do preservice teachers execute in a chemistry class? Are there connections between their intended and performed actions? 
In this sense, we corroborate Moretto's (2007) argument, which deals with planning as the moment of organising teachers' and students' actions, which requires the teacher to know the levels/stages that make up the planning process. Thus, for the preservice teachers, planning configures the actions intended for class, while execution covers the class development, referred to as actions performed.

From this perspective, this research seeks to identify and categorise the preservice teachers' actions intended and performed in a chemistry class they taught during Supervised Practice, with implications for teacher education.

\section{METHODOLOGY}

The data analysed in this research come from monitoring a pair of chemistry preservice teachers from a public university of Paraná, enrolled in Supervised Teaching Practice. ${ }^{1}$

Data was collected through different instruments: the documents related to the school subject - preservice teachers' lesson plans, and audio and video recordings, and field notes made by the researcher as complementary sources. Throughout the recordings, the camera focused on the preservice teachers, since the objective was to investigate them. As the students were not asked for consent for being filmed in class, when the preservice teachers walked around the classroom and carried out any movement with the students' participation, we used the audio and field notes to register the classroom occurrences.

\footnotetext{
${ }^{1}$ The data and information obtained in this article are an integral part of a research approved by the Ethics Committee of the linked university, under number CAEE 57663716.9.0000.5231, opinion number 1.666.360. We reiterate that the research did not offer any psychological and/or physical risk to the participants, who agreed to participate in the research through an Informed Consent Form. The authors of this work assume any risks and explicitly exempt the Acta Scientiae from any consequences, including full assistance and possible compensation for any damage resulting from any of the participants, in accordance with Resolution No. 510, of April 7, 2016, of the National Health Council.
} 
The first class analysed was the preservice teachers' first practice. It consisted of a lecture reviewing the introductory chemistry concepts the teacher in charge had already taught and requested. The preservice teachers took everyday materials ${ }^{2}$ to demonstrate some of the concepts presented and interact with the students. At the end of the class, the teachers summarised the content on the blackboard, and the students registered it in their notebooks.

To analyse and interpret the data through the instruments used (written records and video recordings), we were guided by the assumptions of the discursive textual analysis (DTA), which, according to Moraes and Galiazzi (2011) is composed of (i) deconstruction and unitarisation, (ii) categorisation, and (iii) metatext. For i) deconstruction and unitarisation, we proceeded to several readings and fragmentations of the lesson plan and video/audio transcripts to establish the analysis units submitted to classification. Such units are elaborated "based on the researcher's tacit knowledge, always in line with the research objectives" (Moraes \& Galliazi, 2011, p. 195). In this case, the video fragmentation and transcriptions allowed us to understand the duration and intentionality of the actions, aiming at categorising them.

(ii) categorisation consists of grouping the similar elements of the units of analysis. From establishing categories, the descriptions and interpretations of the research are produced, being necessary to define and name them. Initially, we proposed an analysis using as a priori categories the actions suggested by Andrade and Arruda (2017). The authors identified four major 'categories of action': Bureaucratic-Administrative (BAd); Wait (Esp); Explain (Exp); Write (Esc). However, during the analysis, some categories of action were adapted to the context of this investigation, and others emerged in the process.

As the classes were prepared and taught in duos, it is pertinent to clarify that they were planned together, resulting in a single lesson plan. The partners agreed on alternating the classes so that one preservice teacher managed and explained the concepts, while the other assisted without interfering with the

${ }^{2}$ Everyday materials are low-cost, easily accessible, and operational materials associated with students' routine phenomena. For this class, we can exemplify as everyday materials: chocolate aluminium cans, pet bottles containing water, mixtures of water with sugar and juice. 
peer's conduct. Therefore, both for the unitarisation process and for action categorisation, we considered the one who managed the class. From identifying the analysis units, composed of the verbs that governed the preservice teachers' actions and their grouping by similarities, we present a set of categories of actions for the planning (actions intended) and a set of categories of actions for the class itself (actions performed).

On the other hand, the elaboration of (iii) metatexts comprises the theorisation of the researcher's understandings about the phenomenon studied, when he/she exposes his/her arguments and inferences systematised by the previous stages. In this case, the interpretive movement composes the articulation between the actions intended and the actions performed by the undergraduates in the class, just touching connections and understandings about the actions as a guiding element of the teachers' practice, in this case, the future teachers.

\section{RESULTS AND ANALYSES}

As we aim to identify and categorise the actions intended and performed by preservice teachers in a chemistry class taught during their Supervised Practice, we began the analyses by examining the lesson plan based on the template available for the subject matter, since the context is an initial teacher education course. The curricular supervised teaching practice of the chemistry teaching degree course at stake (research field institution) comprises several steps and activities undergraduates must fulfil before their hands-on practice, such as school reconnaissance and observing of classes taught by the teachers in charge. Those steps subsidise the preservice teachers for planning their classes, which they must systematise through the lesson plan. Santos and Freire (2017) discuss the purpose of planning as a constituent stage of the teaching practice.

During class planning, the undergraduates define the objectives proposed for each class, the development of activities and explanations, the methodology and strategy they will apply, the didactic resources and the assessment criteria they will use. To prepare this teaching plan, the preservice teachers build their knowledge throughout the undergraduate course and their school experience (Santos \& Freire, 2017, p. 265). 
Thus, in the categorisation process, we attribute as macroactions the stages of class planning: introduction, development, and integrative reconciliation. These stages constitute the mandatory elements in the lesson plan template provided by the subject matter, as follows:

Introduction - describes how the student intends to start the lesson.

Development - describes how the student intends to conduct the class in terms of resources and content.

Integrative Reconciliation - describes how the student intends to resume the items included in the previous steps and "close" the class.

From the macroactions, it was possible to identify two other levels of action in the planning (actions and microactions). The actions, governed by representative verbs, can be separated into a set of smaller actions called microactions. The microactions refer to the detailing of the several acts that occurred to cover the actions. Table 1 shows the process of categorisation of the actions intended.

\section{Table 1}

Categorisation of the macroactions, actions and microactions intended

\begin{tabular}{lll}
\hline Macroactions & $\begin{array}{c}\text { Action } \\
\text { S }\end{array}$ & \multicolumn{1}{c}{ Microactions } \\
Introduction & Question & $\begin{array}{l}\text { Ask about the content (the properties of } \\
\text { matter and mixture) } \\
\text { Ask about the content using everyday } \\
\text { materials }\end{array}$ \\
& Explain & $\begin{array}{l}\text { Explain the content (main properties of } \\
\text { the matter -colour, malleability, } \\
\text { hardness, physical state) }\end{array}$ \\
& Identify & $\begin{array}{l}\text { Identify students' previous ideas } \\
\text { Check the didactic material (book) } \\
\text { Organise the class in a row } \\
\text { Deliver initial questionnaire }\end{array}$ \\
& Organise
\end{tabular}




\begin{tabular}{|c|c|c|}
\hline & & Collect initial questionnaire \\
\hline \multirow{6}{*}{$\begin{array}{c}\text { Developme } \\
\text { nt }\end{array}$} & & Explain content (general properties) \\
\hline & & Explain content (mixtures types) \\
\hline & Explain & $\begin{array}{l}\text { Explain content (mixtures separation } \\
\text { processes) }\end{array}$ \\
\hline & & Explain content (atomic models) \\
\hline & & Explain content (periodic table) \\
\hline & Write & $\begin{array}{l}\text { Write on the blackboard (content of } \\
\text { general and specific properties) } \\
\text { Write on the blackboard (mixtures) }\end{array}$ \\
\hline \multirow{2}{*}{$\begin{array}{l}\text { Integrative } \\
\text { Reconciliati } \\
\text { on }\end{array}$} & Write & Write on the blackboard (the schematic) \\
\hline & Identify & $\begin{array}{l}\text { Return questionnaire } \\
\text { Identify students' previous ideas }\end{array}$ \\
\hline
\end{tabular}

With the help of macroactions, we found five different types of actions (question, explain, identify, organise, and write) in the lesson plan. These actions should occur to make each macroaction - planning step - be executed. These actions are described as follows:

Question - this action involves asking questions on some topic.

Explain - in this type of action the teacher explains a content or an exercise.

Identify - this action involves identifying students' ideas and concepts orally or in writing.

Organise - this action involves organising materials and/or the classroom environment. blackboard.

$\underline{\text { Write }}-$ this action involves writing some content or an exercise on the

The microactions refer to the detailing of the several acts that occurred to cover the actions. For example, for the identify action, we understand that its general purpose is to spot the students' previous ideas about the contents worked before. For this action to occur, students need to answer the questionnaire delivered and later collected for this purpose, justifying the 
allocation of these units of analysis as microactions of identification. For the question action, we identified two types of microactions, ask about the content and ask about the content with the aid of everyday materials. The explain action is subordinate to the explanation of the different topics of the content (matter, specific properties of the matter, mixtures, atomic models, and periodic table). For the write action, the undergraduates plan to write on the blackboard the content and the representative scheme in the integrative reconciliation. The organise action, on the other hand, provides for microactions such as organising the class in rows, checking didactic material, distributing questionnaires, and collecting questionnaires.

Andrade and Arruda (2017) note the existence of four categories of teaching action in mathematics classes of the 9th grade, briefly described below:

Bureaucratic-Administrative (BAd): considered as an action before the very act of teaching. Ex: teacher's displacement to the classroom; preparatory actions, such as tidying up the material, calling the roll; some unforeseen actions that interrupt the class, or other actions that the teacher performs before developing the specific teaching actions, such as taking notes in the callbook; and leaving the classroom.

Wait (Esp): the teacher waits for the students' the action, usually exercising some kind of management on the class: management of the topic, when talking to students about the content or asking questions; or class management, when talking, scolding, or drawing the students' attention.

Explain (Exp): comprises material management actions. Ex: explains content or exercise involving or not students' intervention; and teacher's explanation of the class procedures.

Write (Esc): also comprises material management actions. Ex: writes content, writes exercise, etc. (adapted from Andrade \& Arruda, 2017, p.262).

When performing a comparative movement with Andrade and Arruda's research's (2017) results, we found that for the actions intended, i.e., in the action before the class, we found two categories like those the authors had 
found: explain and write, and the absence of two of them: bureaucraticadministrative and wait. It is noteworthy that both explain and write categories presented microactions equivalent to those identified for the mathematics class.

Regarding the absence of the bureaucratic-administrative and wait categories, we evidenced that the undergraduates did not foresee situations when they needed to wait for students to perform tasks or when they needed to perform activities not linked to teaching, such as calling the roll, i.e., they targeted and prioritised actions related to content management.

The process of extracting and categorising the actions provided for in the planning of the preservice teachers in initial education, called in this investigation "actions intended," comprises an unprecedented movement in the group's set of investigations ${ }^{3}$, since previous research addressed in-service teachers' action (Andrade, Arruda \& Passos, 2018; Dias; Arruda; Oliveira \& Passos, 2017).

Regarding the class development, to characterise the actions performed by the preservice teachers in the class, we transcribed the 87-minute-long video (equivalent to $2 \mathrm{~h} / \mathrm{class}$ ), unitising the microactions for further categorisation. To this end, we resumed the video as many times as necessary to write down the exact times of the actions and understand the context in which the debatable actions occurred, to assist in grouping the units of analysis and allocating them into categories. Table 2 shows the description of the categories of action identified and their respective microactions. To illustrate the representativeness of the actions during the class, we indicate the time of occurrence of the actions.

\section{Table 2}

Categories of action and microactions performed for the class

Actions Description Microactions

${ }^{3}$ Research group linked to the Postgraduation Programme in Science Teaching, whose research program has as its theme of interest the investigation of teaching action. 


\begin{tabular}{|c|c|c|}
\hline Demonstrate & $\begin{array}{l}\text { This category } \\
\text { refers to the } \\
\text { demonstration of }\end{array}$ & $\begin{array}{l}\text { - Show material to students } \\
\text { - Show the bottle to the students } \\
\text { - Show the bottle } /^{4} \text { explain the } \\
\text { content }\end{array}$ \\
\hline & $\begin{array}{l}\text { everyday materials } \\
\text { for students }\end{array}$ & $\begin{array}{l}\text { - Show the aluminium can/ } \\
\text { explain the content }\end{array}$ \\
\hline & $\begin{array}{l}\text { This category } \\
\text { refers to }\end{array}$ & $\begin{array}{l}\text { - Explain about class conduction } \\
\text { - Explain the content }\end{array}$ \\
\hline Explain & $\begin{array}{l}\text { explanations about } \\
\text { the class content }\end{array}$ & $\begin{array}{l}\text { - Explain content / pick up } \\
\text { material from the backpack }\end{array}$ \\
\hline & $\begin{array}{l}\text { with or without the } \\
\text { support of } \\
\text { demonstrative }\end{array}$ & $\begin{array}{l}\text { - Explain scheme / displace } \\
\text { - Explain the content/flip } \\
\text { through material }\end{array}$ \\
\hline & $\begin{array}{l}\text { materials, or } \\
\text { explanations about } \\
\text { the class } \\
\text { development. }\end{array}$ & $\begin{array}{l}\text { - Explain by pointing at the } \\
\text { blackboard }\end{array}$ \\
\hline Оиес & $\begin{array}{l}\text { This category } \\
\text { refers to the times }\end{array}$ & $\begin{array}{l}\text { - Ask about the material/show } \\
\text { everyday material }\end{array}$ \\
\hline Ques & when teachers & - Ask about the content \\
\hline & $\begin{array}{l}\text { make intentional } \\
\text { questions about the } \\
\text { content }\end{array}$ & - Offer material to the student \\
\hline \multirow{6}{*}{ Talk } & Refers to & - Talk to the teacher educator \\
\hline & conversations & - Talk to peer \\
\hline & on subjects not & - Talk to the students \\
\hline & directly related to & - Talk to supervisor teacher \\
\hline & $\begin{array}{l}\text { the lesson. In this } \\
\text { case, there is talk }\end{array}$ & $\begin{array}{l}\text { - Talk to peer/flip through lesson } \\
\text { plan }\end{array}$ \\
\hline & $\begin{array}{l}\text { with the teachers, } \\
\text { the colleague, and } \\
\text { the students. }\end{array}$ & $\begin{array}{l}\text { - Talk to peer while holding } \\
\text { material }\end{array}$ \\
\hline \multirow{2}{*}{ Guide } & $\begin{array}{l}\text { Actions in which } \\
\text { teachers provide }\end{array}$ & $\begin{array}{l}\text { - Guide on the resolution of the } \\
\text { questionnaire }\end{array}$ \\
\hline & $\begin{array}{l}\text { guidance on } \\
\text { activities }\end{array}$ & $\begin{array}{l}\text { - Guide on the delivery of the } \\
\text { questionnaire }\end{array}$ \\
\hline
\end{tabular}

${ }^{4}$ The slash (/) is used to indicate two simultaneous actions. 
- Guide on the content of the next class

\begin{tabular}{|c|c|c|}
\hline Accept & $\begin{array}{l}\text { Accept answers } \\
\text { provided by } \\
\text { students }\end{array}$ & - Accept the student's answer \\
\hline Write & $\begin{array}{l}\text { Just write on the } \\
\text { blackboard: the } \\
\text { theory or } \\
\text { schematic } \\
\text { representation of } \\
\text { the content }\end{array}$ & $\begin{array}{l}-\quad \text { Write on the } \\
\text { blackboard/explain content } \\
- \text { Write on the blackboard }\end{array}$ \\
\hline Wait & $\begin{array}{l}\text { Wait for students } \\
\text { to answer the } \\
\text { written } \\
\text { questionnaire or } \\
\text { oral questions }\end{array}$ & $\begin{array}{l}\text { - Wait for the student to take the } \\
\text { liquid } \\
\text { - Wait for students to answer the } \\
\text { questionnaire } \\
\text { - Wait for students to answer oral } \\
\text { questions }\end{array}$ \\
\hline Displace & $\begin{array}{l}\text { This category } \\
\text { refers to the } \\
\text { preservice } \\
\text { teachers' } \\
\text { displacement } \\
\text { inside or outside } \\
\text { the room. }\end{array}$ & $\begin{array}{l}\text { - Move towards the group } \\
\text { - Move around the room quietly } \\
\text { - Move towards the table } \\
\text { - Move towards the blackboard } \\
\text { - Move to drink water }\end{array}$ \\
\hline Start Timer & $\begin{array}{l}\text { This category } \\
\text { refers to the } \\
\text { actions taken to } \\
\text { manage the } \\
\text { activity time, the } \\
\text { class time. }\end{array}$ & $\begin{array}{l}\text { - Time class on mobile } \\
\text { - Time class on clock }\end{array}$ \\
\hline Consult & $\begin{array}{l}\text { Understands } \\
\text { actions in which } \\
\text { the teacher refers } \\
\text { to printed support } \\
\text { materials to } \\
\text { continue the class }\end{array}$ & $\begin{array}{l}\text { - Refer to support material on the } \\
\text { table }\end{array}$ \\
\hline
\end{tabular}




\begin{tabular}{|c|c|c|}
\hline Organise & $\begin{array}{l}\text { Comprises teacher } \\
\text { actions required to } \\
\text { organise the class, } \\
\text { such as organising } \\
\text { materials in folder, } \\
\text { collecting material, } \\
\text { erasing the } \\
\text { blackboard. }\end{array}$ & $\begin{array}{l}\text { - Organise the material of the } \\
\text { folder } \\
\text { - Organise questionnaires } \\
\text { - Close the backpack } \\
\text { - Place material on the table } \\
\text { - Distribute the questionnaire } \\
\text { - Collect the questionnaire } \\
\text { - Erase the blackboard }\end{array}$ \\
\hline Scold & $\begin{array}{l}\text { Scold students for } \\
\text { disturbing the class } \\
\text { due to noise }\end{array}$ & $\begin{array}{l}\text { - Tell the students to remain } \\
\text { silent }\end{array}$ \\
\hline
\end{tabular}

We can see that 13 categories of action emerged in the trainees' class taught (demonstrate, write, explain, question, guide, talk, organise, start a timer, accept, displace, consult, and scold). Some of those actions already located in previous research (Andrade, Arruda \& Passos, 2018; Dias, 2018) such as displace, explain, write, wait, organise, and scold were adapted to the context of this investigation. Microactions guided this process because they allowed a new meaning in the description of the category. For example, the organise action in Dias' research (2018) refers to "organising into groups: separating into groups; changing the arrangement of groups," aiming to organise students to perform a mathematics activity in groups, using manipulable materials. On the contrary, in this research, the organise action comprises microactions in which the undergraduates are guided by organising their own didactic action (organising material in the folder, closing the backpack, erasing the blackboard) instead of organisational aspects directly involving students, such as placing students in the class, since the objectives of the class were also different.

Seven new categories, non-converging with previous research, also emerged: demonstrate, question, guide, talk, time, accept, and consult.

Regarding the categorisation process, we interpreted and allocated the actions resulting from what we observed to be the main objective of the movement in question because, on several occasions, there were simultaneous actions. As an example, in the microaction explain the content/ move around the room, the trainee moved frequently while explaining the content, however, we understand that when this occurred, the basic action was to explain, because 
the displacement occurred incidentally, not as the main objective of the action. Thus, the displace action refers to when the trainee moves out of the room to drink water, erase the board, etc.

To visualise better the representativeness of the actions during the class, Figure 1 presents the occurrence times for each.

\section{Figure 1}

Time of occurrence of the actions performed

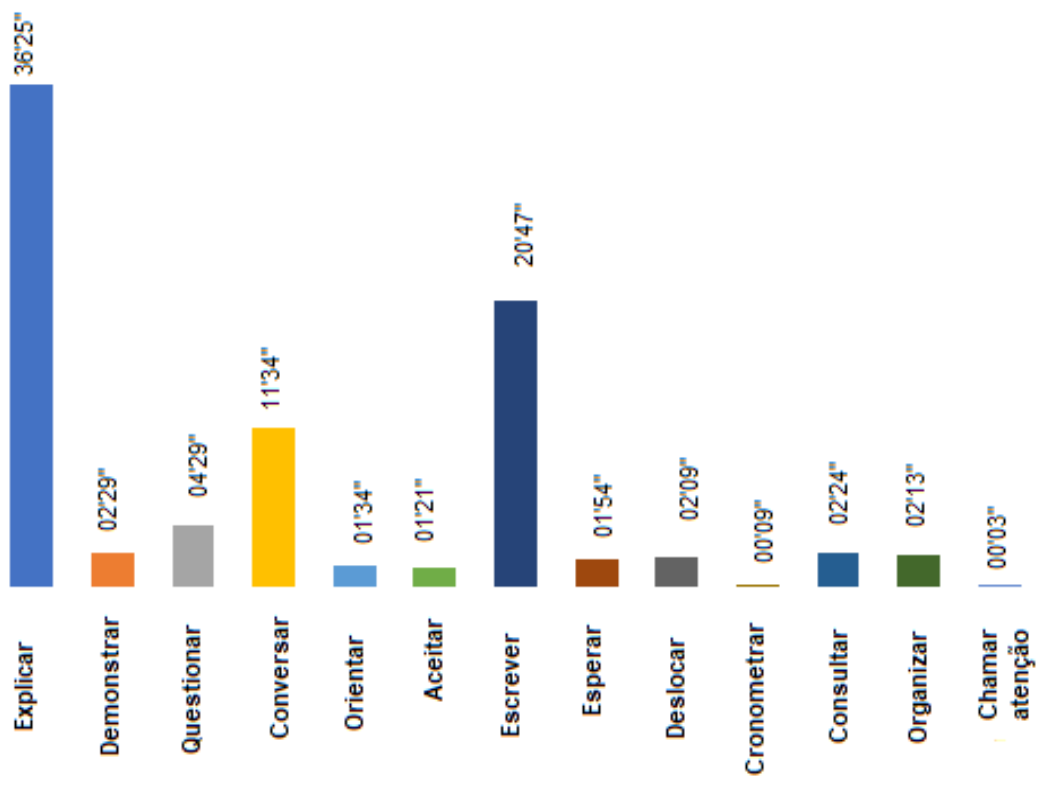

In this investigation, wait refers almost exclusively to waiting time for oral questions, giving a short time [01'54'] to the wait action, unlike a classroom context of a teacher in charge, as evidenced by Andrade (2016). In the time allotted to students to answer the questionnaire, the trainee's main action was to quietly talk to the peer, the supervisor teacher, the teacher educator, exchanging ideas and discussing the class and the preparation of the 
classes to come. At certain times, they even consulted the plan and the support material. This fact contributed to the long duration of the talk action [11'34"']. We interpreted that during the period students spend answering the initial and final questionnaires, the undergraduates tried to organise the class, exchange ideas, and browse through the material, seeking feedback and projecting the next actions.

The guide-type actions refer to guidelines that the preservice teachers pass to the whole class, informing them about the progress of the class, how to proceed to resolve the questionnaire, guiding them to close the books to solve it. These are not actions linked to content explanation. Thus, they are not allocated in the action intended to explain, nor are they informal conversations with students separately, so we also do not configure them as talk-type actions.

The accept action stems from situations in which the undergraduates accept students' answers after some asking about the content. Due to the class characteristic (review), students had already studied the content with the supervisor teacher, so, most of the times, they were requested to respond promptly to the question. When they did not answer, the preservice teacher would wait, and, not getting an answer, he/she went on with the class.

As is the case with the action scold [00'03'], some actions barely occurred, appearing only once at the beginning of the class. However, the low frequency of this action symbolises and reaffirms the class characteristics and conditions. As it was the preservice teachers' first teaching experience, the class did not manifest episodes of disciplinary problems. The actions start timer [00'09'], organise [02'13']. and consult [02'24'] are important not by the total of the time of occurrence, but by the regularity that indicates the class understanding. The undergraduates were concerned with classroom management, trying to manage time with the clock and/or mobile phone several times, recurrently consulting the support materials and the lesson plan (that was on the table). Also, the organisational aspect, represented in the organising category, was present with microactions such as organising the board, collecting questionnaires, storing the materials used, etc.

When comparing the actions performed in the class with the actions identified by Andrade and Arruda (2017) in mathematics classes, we interpret it as the only action that approaches an action of a bureaucratic-administrative character, refers to displacement (displace), since it does not imply situations 
directly linked to teaching. This displacement occurs during the class and includes microaction such as: move to drink water and move towards the board, taking around $2.4 \%$ of the class time.

In an attempt to confront the actions initially planned, and seeking to understand what actually occurs during the classes, we connected the categories of action and microactions emerging from the actions intended and performed for each macroaction (introduction, development, and integrative reconciliation), which were summarised in the subsequent tables. Table 3 illustrates the connection between the actions intended and performed for the introduction of the class.

\section{Table 3}

Intended actions $x$ actions performed for the macroaction Introduction

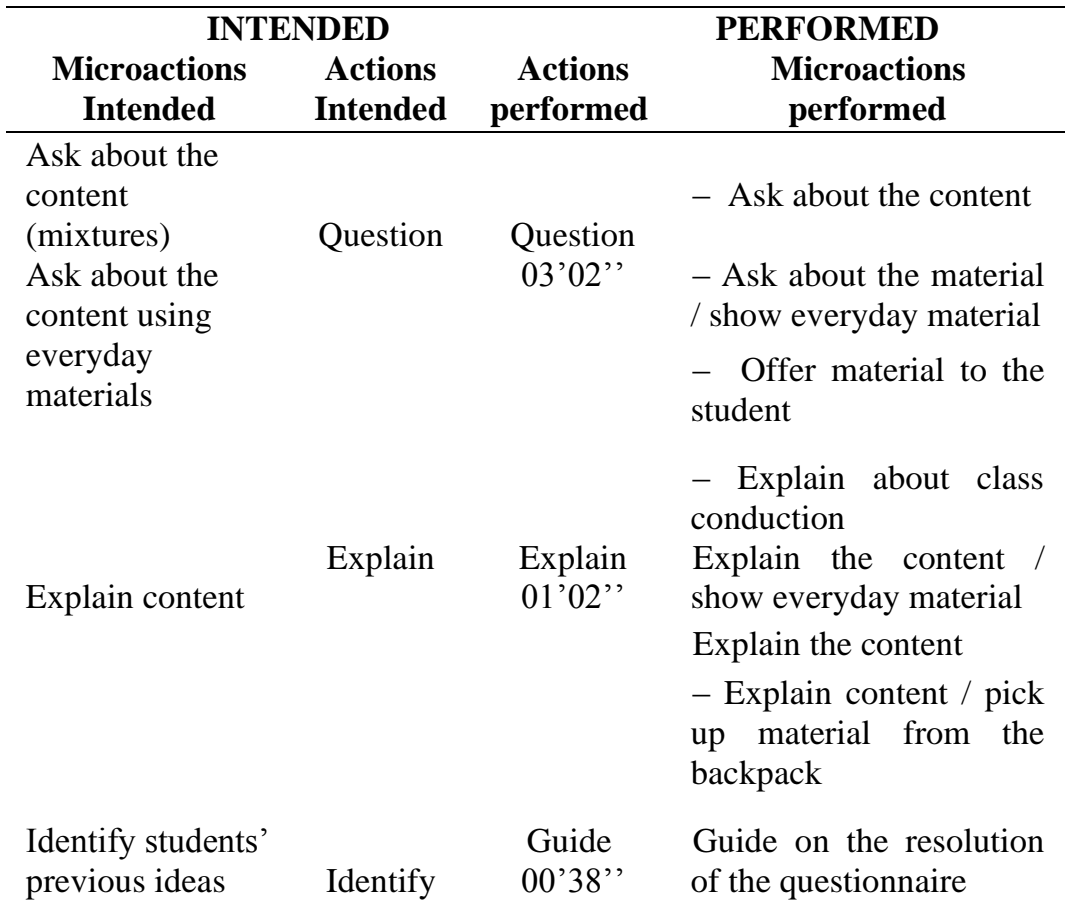


Check the

didactic material

(book)

Organise the

class in a row
- Guide on the delivery of the questionnaire

- Organise the material of the folder

Organise Organise 00'58',

Organise questionnaires

Close the backpack

Place material on the table

Distribute the questionnaire

Demonstrat Demonstrate everyday e material

01'33', Demonstrate material/explain content

Talk to teacher educator Talk to peer Talk to the students

Talk Talk to Supervising 04'31" Teacher

Talk to peer/hold material

Talk to peer/consult plan

Displace Move towards the 01'18', group/talk

Move around the room

Start Time class on clock

Timer

00 '05',

Wait Wait for students to $01^{\prime} 55^{\prime}$, answer

Accept Accept the students' idea 00'21',

Consult Consult support material 00'25', 
The introductory basis of this class, defined after the discussions in the planning phase, was based on the use of everyday materials to promote questions for students (question) to review the content, resuming the explanation of concepts (explain). The questionnaire would also serve to identify students' ideas on the topics presented (identify) and as data collection for the undergraduates' supervised hands-on practice portfolio. As to those actions proposed, with the aid of Chart 3 , we can verify that all those actions intended were implemented.

The question action makes a total of [03'02''], delimiting one of the representative actions of the class, illustrated in Figure 3 (Explain $>$ Write $>$ Talk $>$ Question $>$ Demonstrate). In line with the intended actions, two microactions were performed and a microaction emerged, offering material to the student, which we infer its incidence is due to the class context and dynamism. The material used was a plastic bottle that contained a mixture of water with which the trainee explained the concept of homogeneous and heterogeneous mixtures. Given the class situation, the trainee improvised and offered the bottle to the student, asking a question about the content. This action led to a new microaction, but which meets the objectives initially proposed (ask about the content).

Moreover, the use of everyday materials for questioning provided the emergence of a new category of action of the type demonstrate. To demonstrate everyday materials (aluminium can, plastic lid, pet bottles with different mixtures) the undergraduates showed them before or after the questions, handling them to differentiate the general and specific properties of the materials and the types of homogeneous and heterogeneous mixtures several times. The use of low cost and easy-to-acquire materials in science/chemistry classes is an important alternative, as it enables demonstrative experimentation and visualisation of the macroscopic phenomenon even in the absence of infrastructure and science laboratories (Santos et al., 2018; Machado, 2019).

Organisational actions were also planned to assist in class management, such as verifying row organisation. From the didactic point of view, check whether the students had the individual didactic material (the book). We can 
observe that the organisational microactions were the only ones that the preservice teachers did not carry out during class. On the other hand, they performed others of another nature, related to the organisation of the material and support resources used during the class (questionnaire, lesson plan, everyday materials).

Dias, Arruda, Oliveira, and Passos (2017) found actions such as question, in which the teacher asks questions about a diversity of subjects, not specifically about the content: the teacher asks the date, whether he/she can resume [the class], and why the student is standing. For this investigation, we categorised the action as question, because there is the intentionality of specific questions about the content.

Besides, new actions and microactions emerge in the introductory part of the class: scold, accept, wait, are types of actions not initially foreseen in the teaching plan and refer to actions resulting from interaction with students: telling them to remain silent, accepting the answers to the questions, waiting to finish the activities. The occurrence of those actions is conditioned to the student's participation in the class.

The category scold emerges as class management, necessary to maintain order in the class and be able to speak, in line with the action category found by Dias, Arruda, Andrade, and Passos (2017). It is noteworthy that such action occurred only once, maybe because it was the trainees' first teaching opportunity. Also, there were several teachers in the room, causing the students to feel shy and reserved. The displace action refers to microactions in which the teacher moves inside or outside the room space with the class in progress. Some microactions are meant to manage the class: move towards the board; move to pick up the questionnaire.

$\underline{\text { Talk}}$, consult, and start timer actions emerge because it is a context of initial teacher education, i.e., the supervised practice. Because they are teachers in a formative process, there were some actions based on time management (start timer) to meet the established time and consultation of support material and the lesson plan at several times (consult), arising from insecurity, as it was the first class the pair was teaching. Also, as a reinforcement, we infer the diversity of microactions of the talk type. The trainee talked to the teacher educator (who was present in the class at stake), the supervisor teacher, the students, and to each other, given the specificity of the practice to be carried 
out in duos. In a class taught by the teacher in charge of the class, in a routine context, the teacher does not interact with supervisors who assess, nor teach classes collectively. Therefore, we understand that such microactions constitute detailed actions of the talk category of action, an action characteristic of a supervised teaching practice context. Table 4 presents the connections between the actions intended and the actions performed for the macroaction - Class development.

\section{Table 4}

Actions intended $x$ actions performed for the macroaction development

\begin{tabular}{|c|c|c|c|}
\hline \multicolumn{2}{|c|}{ INTENDED } & \multirow[b]{2}{*}{$\begin{array}{l}\text { Actions } \\
\text { performed }\end{array}$} & \multirow{2}{*}{$\begin{array}{c}\text { PERFORMED } \\
\text { Microactions } \\
\text { performed }\end{array}$} \\
\hline $\begin{array}{l}\text { Microactions } \\
\text { Intended }\end{array}$ & $\begin{array}{c}\text { Actions } \\
\text { Intended }\end{array}$ & & \\
\hline $\begin{array}{l}\text { Explain content } \\
\text { (mixtures, } \\
\text { atomistic, periodic } \\
\text { table) }\end{array}$ & Explain & $\begin{array}{l}\text { Explain } \\
\text { 33'36'" }\end{array}$ & $\begin{array}{l}\text { Explain } \\
\text { content/move around } \\
\text { the room } \\
\text { Explain content }\end{array}$ \\
\hline \multirow[t]{5}{*}{$\begin{array}{l}\text { Write on the } \\
\text { blackboard } \\
\text { (mixtures, atomic } \\
\text { models, periodic } \\
\text { table) }\end{array}$} & Write & $\begin{array}{l}\text { Write } \\
15^{\prime} 13^{\prime},\end{array}$ & $\begin{array}{l}\text { Write on the } \\
\text { blackboard } \\
\text { Write on the } \\
\text { blackboard/explain } \\
\text { content }\end{array}$ \\
\hline & & $\begin{array}{c}\text { Demonstrat } \\
\text { e } \\
00^{\prime} 56^{\prime}\end{array}$ & $\begin{array}{l}\text { Demonstrate } \\
\text { material/explain } \\
\text { content }\end{array}$ \\
\hline & & $\begin{array}{l}\text { Displace } \\
00^{\prime} 51^{\prime},\end{array}$ & $\begin{array}{l}\text { Move around the } \\
\text { room quietly } \\
\text { Move to the table }\end{array}$ \\
\hline & & $\begin{array}{l}\text { Organise } \\
00^{\prime} 222^{\prime}\end{array}$ & $\begin{array}{l}\text { Organise material on } \\
\text { the table } \\
\text { Erase the blackboard }\end{array}$ \\
\hline & & Talk & Talk to students \\
\hline
\end{tabular}




\begin{tabular}{|c|c|}
\hline $01^{\prime} 16^{\prime \prime}$ & Talk to peer \\
\hline $\begin{array}{l}\text { Question } \\
01^{\prime} 17^{\prime},\end{array}$ & Ask about the content \\
\hline $\begin{array}{l}\text { Consult } \\
01^{\prime} 38,\end{array}$ & $\begin{array}{l}\text { Consult support } \\
\text { material }\end{array}$ \\
\hline $\begin{array}{l}\text { Accept } \\
00^{\prime} 31^{\prime},\end{array}$ & $\begin{array}{l}\text { Accept the students' } \\
\text { idea }\end{array}$ \\
\hline $\begin{array}{c}\text { Wait } \\
00^{\prime} 44^{\prime},\end{array}$ & $\begin{array}{l}\text { Wait for students to } \\
\text { answer }\end{array}$ \\
\hline \multirow[t]{2}{*}{$\begin{array}{l}\text { Guide } \\
\text { 00'06,' }\end{array}$} & $\begin{array}{l}\text { Guide students to } \\
\text { close the notebook }\end{array}$ \\
\hline & $\begin{array}{l}\text { Guide on the next } \\
\text { class }\end{array}$ \\
\hline $\begin{array}{l}\text { Organise } \\
00^{\prime} 22^{\prime},\end{array}$ & $\begin{array}{l}\text { Organise material on } \\
\text { the table }\end{array}$ \\
\hline $56^{\prime} 24^{\prime \prime}$ & \\
\hline
\end{tabular}

For the class development, the pair of trainees predicted actions of two types, explain and write, typical of a class of concept review, based on content resumption. Such actions were covered in the execution phase and represent the majority amount of time of this macroaction [48'49'], complying with the objective outlined for this step (write: [15'13'']; explain: [33'36']).

Concurrently, we observe the emergence of a variety of categories of action analogous to those that emerged in the Introduction (demonstrate, question, talk, wait, accept, displace, consult, organise). However, despite covering categories of actions performed similar to the introduction, the frequency with which these actions occurred differs in each macroaction and there is a variation of microactions, not being allocated in the class introduction. In the macroaction introduction, the microactions of the guide action were linked to the questionnaire delivered to the students: guidelines to solve the questionnaire, deliver guidelines. For the class development, the guide microactions refer to storing the didactic material and guidance on conducting the sequence of subsequent classes. This also denotes changes in the 
frequencies of these actions, because the trainee took longer [00'38'] to guide on the questionnaire than in to develop the class [00'06'].

Another example refers to the action to write, predict, and execute during class development macroaction. The trainees used more than 15 minutes [15'13' '] on the blackboard, while at the beginning of the class this action did not reach the first minute [00'38'] . Therefore, the frequency of occurrence and the duration of the actions favoured important indications for the understanding of the actions that manage the class.

Some actions and microactions, such as question (ask about the content) and demonstrate (demonstrate material/explain) that were not planned for the macroaction class development, focused on this stage of the class. During the explanation, the preservice teachers took the material (pet bottle) and demonstrated to the students to explain and differentiate the concept of mixture. It also conducts several questions from examples of processes of separation of mixtures in everyday life, encouraging students to participate, and denoting the occurrence of the wait action

This fact indicates a familiarisation with the strategy adopted, extending its use to other stages, albeit timidly (demonstrate: [00'56']; question: [01'17' ']) and of short duration, which means that the undergraduates used the ability to improvise in a positive bias, taking advantage of the material available.

Only two actions identified in the Introduction did not occur in class development (timing, scolding). The absence of these actions is justified by the teacher's willingness to work on the content without activities to manage the start/end time, and there were no disciplinary episodes in which the teacher in training had to maintain order in the room.

Finally, Table 5 illustrates the connections between actions intended and performed for the integrative reconciliation of the class.

\title{
Table 5
}

Actions intended $x$ actions performed for the macroaction Integrative Reconciliation.

\author{
INTENDED PERFORMED
}




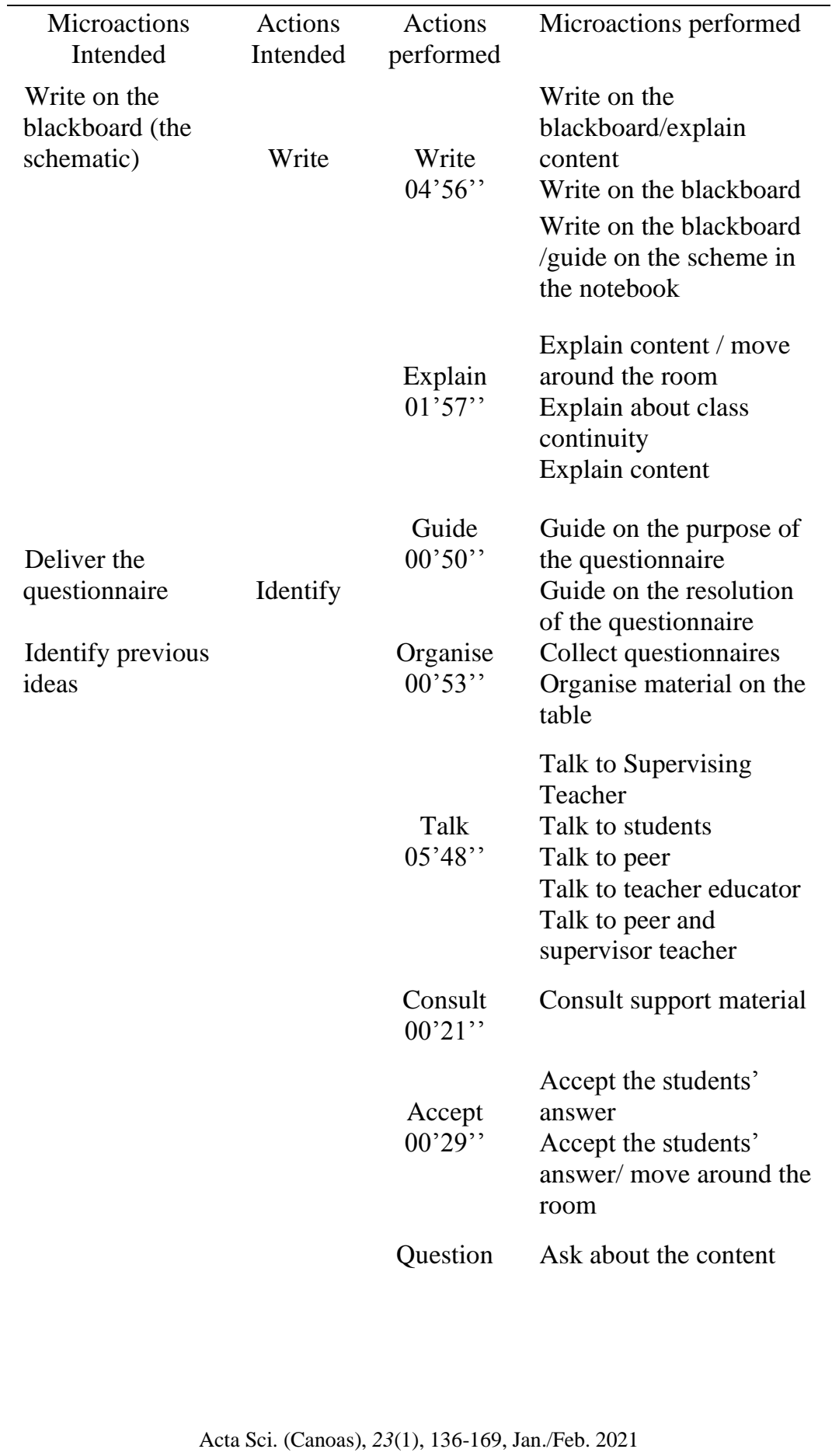




\begin{tabular}{|c|c|}
\hline $\begin{array}{c}\text { Wait } \\
00^{\prime} 12^{\prime},\end{array}$ & $\begin{array}{l}\text { Wait for students to } \\
\text { answer }\end{array}$ \\
\hline $\begin{array}{l}\text { Guide } \\
00^{\prime} 50^{\prime},\end{array}$ & $\begin{array}{l}\text { Guide students to close } \\
\text { the notebook } \\
\text { Guide on the next class }\end{array}$ \\
\hline $\begin{array}{l}\text { Start Timer } \\
00^{\prime} 04^{\prime},\end{array}$ & Time class on clock \\
\hline $16^{\prime} 42^{\prime \prime}$ & \\
\hline
\end{tabular}

Again, the actions planned (write and identify) are present in the actions performed. For this stage, the undergraduates planned to identify the students' ideas through a final questionnaire with the same questions as the initial questionnaire, aiming at comparing them. To resume, they proposed to set up a scheme on the blackboard to summarise all concepts worked. Thus, as well as the presumed, one of the actions that denote more time in this step is write [04'56']. However, the longest-lasting action is talk [05'48' $]$, because the preservice teacher uses the time in which students answer the questionnaire to discuss about the class with the peer and the teachers who guide him/her (both the school and the university).

Just like what occurred in the class development, the same categories of the introduction emerged, except for the scold, demonstrate, and displace actions. The undergraduates no longer use everyday material and limit themselves to using the blackboard to write the scheme proposed, also inhibiting the possibility of displacement.

As illustrated in Figure 3, the introduction macroaction manages the actions of the other stages of the class. Thus, the strategy of using everyday materials in a demonstrative way for the review class generated an introductory basis with four actions intended: question, explain, identify, and organise. During class, the undergraduates performed such actions, while other actions unfolded (question, demonstrate, accept). Those introductory actions, the result of discussions in guidelines, guided the other class macroactions, because, during the class (development and integrative synthesis), such actions were present. 
It is possible to notice that the preservice teachers wanted to meet the actions initially intended and that, despite proposing to question the students only in the introduction, macroaction in which this action was more incisive [03'02"]; this action also emerged in the other macroactions of the class (development [01'17' ']; integrative reconciliation [00'50']). Regarding the duration of the action question [04'09' '], we understand it constitutes the beginning of the teaching practices, which influenced both the preservice teachers and the students. To the preservice teachers, we attributed it to their initial lack of confidence and anxiety, and to the students, the inhibition in participating and answering the questions due to the insertion of "new" teachers in the room.

Tardif and Lessard (2014) list as teachers' main tasks the teaching, surveillance, student activities, review activities, and organisation of student activities. In this sense, for this class analysed, we found examples of actions directed to teaching (explain, write, question, demonstrate), student activities (wait to answer the questionnaire), and organisation of student activities (organise material in the folder, collect questionnaires). Actions that represent surveillance activities (scold) barely occurred, and review activities actions were not identified. Regarding those actions (surveillance and review activities), we attribute them to the context of the research, since it is the first teaching practice of the preservice teachers.

We also point out the absence of simultaneous actions in the actions proposed by the preservice teachers in the planning phase. Therefore, there is an understanding that the undergraduates systematised actions in the lesson plan that they considered to be a priority. However, in the context of the real classroom, to meet the demands of school organisation, they performed several concomitant actions, for example: explaining while writing on the board.

Therefore, the actions intended are a necessary scope of the actions performed in the teaching practice, however, we must understand the teaching action in a multifaceted bias as signalled by Perrenoud (2000), which goes beyond the line of discourse and enters the direct observation of the doing in the classroom. Thus, the results of this investigation reiterate the importance of investigating the teaching action of the "real" bias, based on "doing" and classroom occurrences, to understand the complexity of the teacher's work and 
provide solid and sustained discussions on implications for teaching-learning and teacher education.

\section{CONCLUSIONS}

The actions intended were systematised by the preservice teachers in the lesson plan, in a movement to synthesise the intentions for the class, in the face of the discussions between the pair of preservice teachers and the teacher educator of the discipline. The actions performed refer to those that actually occur in the classroom. In the process of categorisation of actions (both intended and executed) we defined three levels of actions practiced by the preservice teachers: macroaction, action, and microaction. The macroactions correspond to a priori categories, referring to the normative stages of the supervised teaching practice subject matter to prepare the lesson plan (introduction, development, and integrative reconciliation). The actions are governed by verbs representative of the actions developed for each macroaction and the microactions comprise the detailing of the actions involving the relationship with objects/subjects of the action, responsible for the occurrence of such action.

Through the questions that guided this investigation, we found a set of five categories of action intended (question, identify, write, explain, and organise), which were contemplated in the execution phase. Regarding the development of the teaching practice, besides the execution of the five actions intended in the planning phase, eight more categories of actions emerged, in a total of a set of 13 actions performed for a chemistry review class using the demonstration of everyday materials. We infer that the emphasis and predominance of the actions explain and write comes precisely from the characteristics and objectives of the class (review the content in an expository manner with the support of the blackboard).

By articulating the actions intended and performed for each macroaction of the class, it was possible to visualise that, in general, the base of actions intended is maintained, with the emergence of new actions, which we interpret as unfolding of the actions intended, made possible due to the actions initially planned. For example, when proposing the action question, the pair of trainees did not foresee in the plan the accept or wait of the answers to 
the question, but these actions were only possible from the initiative of question. The emergence of the type of action demonstrate was also made possible due to the use of materials taken by trainees.

Moreover, categories of action and microactions characteristic of the initial training process emerged, i.e., those linked to their teaching in the supervised practice, such as consult (consulting support material and lesson plan), start timer (timing of activities) and talk (talking to peer, with supervisor teachers and teacher educators), which had not yet been located in research to categorise actions for in-service teachers.

Andrade (2016) argues that every teacher's action is related to other facts that permeate the classroom, whether they come from the external environment or within the classroom. The results of this investigation allow us to reinforce these findings by inferring that the preservice teachers' action in the classroom is conditioned to the actions intended, which serve as the basis for the actions performed in the classroom. Furthermore, during class, undergraduates' actions emerged due to interaction with the students, such as wait. The waiting time for the students to answer the questionnaire was only possible due to the students' participation in the classroom and had not been foreseen.

We understand that the actions that occur beyond the actions intended are part of the interactivity that accompanies teaching, as proposed by Tardif and Lessard (2014), and raise important elements for the education of the preservice teacher, such as time management actions (start timer), classroom management (scold), and organisational aspects (organise).

The maintenance of the actions intended during the class is a relevant aspect for the professional development of the undergraduates, as it denotes their commitment with the planning carried out together with the teachers (educator and supervisor) and with the completion of the discipline. Therefore, we assume the importance of the curricular component of Supervised Teaching Practice for the formative process of preservice chemistry teachers regarding the systematisation of the actions intended and developments of such actions during their performance in class. 


\section{AUTHORSHIP CONTRIBUTION STATEMENT}

SMA supervised the development of NDSA's research project, whose results are presented in this article. NDSA was responsible for the preliminary data collection and analysis. FCDB and SMA collaborated to understanding the analysis and conducting the articulations that gather ideas to the studied framework. Both authors discussed and contributed to the final version of this article.

\section{DATA AVAILABILITY STATEMENT}

The data supporting the results are available at https://drive.google.com/drive/folders/11TB3FQ6MO67wcQTkElkRjj UpxFUNbTxK?usp=sharing

\section{REFERENCES}

Andrade, E. (2016). Um estudo das ações de professores de matemática em sala de aula. (191f.). Tese, Doutorado em Ensino de Ciências e Educação Matemática, Universidade Estadual de Londrina.

Andrade, E., \& Arruda, S. de M. (2017). Categorias das ações didáticas do professor de Matemática em sala de aula. Acta Scientiae, 19(2), 254276.

Arruda, S. de M., \& Passos, M. M. (2017). Instrumentos para a análise da relação com o saber em sala de aula. Revista de Produtos Educacionais e Pesquisa em Ensino, 1(2), 95-115.

Andrade, E., Arruda, S. de M., \& Passos, M. M. (2018). Descrição da ação docente de professores de Matemática por meio da observação direta da sala de aula. Educação Matemática Pesquisa, 20(2), 349-368.

Azzi, S. (1999). Trabalho docente: autonomia didática construção do saber pedagógico. In: S. Pimenta (Org.), Saberes pedagógicos e atividade docente (35-60). Cortez. 
BARROS, E. M. D. (2013). O trabalho do professor sob o ponto de vista dos gestos didáticos. Revista Brasileira de Linguística. Apl., 13(3), 741769 .

Dias, M. P. (2018). As ações de professores e alunos em salas de aula de matemática: categorizações e possíveis conexões. (158f.). Dissertação, Mestrado em Ensino de Ciências e Educação Matemática, Universidade Estadual de Londrina, Londrina.

Dias, M. P., Arruda, S. de M., Oliveira, A. C., \& Passos, M. M. (2017). Relações com o ensinar e as categorias de ação do professor de matemática. Caminhos da Educação Matemática em Revista/Online, $7(2), 66-75$.

Goulart, A. O.F. G., \& Vermelho, S. C. D. S. (2019). Ação docente: um diálogo com o campo da pesquisa em ensino de ciências no Brasil. Revista Ciências \& Ideias, 10(2), 150-158.

Machado, C. (2019). Atividades laboratoriais com materiais de baixo custo: um estudo com professores timorenses. Revista Electrónica de Enseñanza de las Ciencias, 18(1), 198-223.

Moraes, R., \& Galiazzi, M. do C. (2011). Análise textual discursiva. (2a ed.). Unijuí.

Moretto, V. P. (2007). Planejamento: planejando a educação para o desenvolvimento das competências. Vozes.

Murta, A. M. G. (2008). Da atividade prescrita ao real da atividade: análise da atividade docente em uma escola regular, sob a perspectiva da Psicologia Sócio-Histórica e da Clínica da Atividade. (233f.). Tese, Doutorado em Psicologia, Pontifícia Universidade Católica de São Paulo, São Paulo.

Perrenoud, P. (2000). Dez novas competências para ensinar. Artmed.

Pimenta, S. G., \& Lima, M. S. L. (2012). Estágio e docência. (3a ed.). Cortez.

Raymundo, G. M. C. (2011). Prática de ensino e estágio supervisionado: eixos articuladores na formação inicial dos professores da educação 
básica. (231f.). Tese, Doutorado em Educação, Pontifícia Universidade Católica de São Paulo, São Paulo.

Quadros, A. L., \& Giordan, M. (2019). Rotas de transição modal e o ensino de representações envolvidas no modelo cinético molecular. Investigações em Ensino de Ciências, 24(3), 74-100.

Santos, P. M. L. dos, Santos, F. L. dos, Lira, L. M. de, Teixeira Júnior, W. J., \& Lima, T. C. (2018). Experimentos de baixo custo para as aulas no laboratório de ciências da escola: uma oficina para professores. Revista de Educação, Ciências e Matemática, 8(3), 141-150.

Santos, E. A., \& Freire, L. I. F. (2017). Planejamento e aprendizagem docente durante o estágio curricular supervisionado. ACTIO: Docência em Ciências, 2(1), 263-281.

Tardif, M., \& Lessard, C. (2014). O trabalho docente: elementos para uma teoria da docência como profissão de interações humanas. (9a ed.). Vozes. 
